\title{
Use of Cartographic Modeling for Assessment of Land Degradation of Damietta Governorate, Egypt
}

\author{
R. R. Ali ${ }^{2}$, M. I. El-Gammal ${ }^{1}$ and R. M. Abou Samra ${ }^{1}$ \\ ${ }^{1}$ Environmental Science Department, Faculty of Science, Damietta University, Egypt. \\ ${ }^{2}$ Soils and Water Department, National Research Centre, Cairo, Egypt.
}

Received: 24 May 2015 / Accepted: 7 October 2015

\begin{abstract}
This study aims to assess the land degradation of Damietta governorate by using the cartographic modeling. To fulfill this objective a number of 18 soil profiles, representing different mapping units were studied. Thirty six soil samples were collected for laboratory analysis. Field work and soil analyses were linked with their relevant mapping units. A simple cartographic model was designed on bases of the international framework for evaluating the land degradation. The results indicated that a significant area of the governorate is threatened by high degradation hazard.

Keywords: Land Degradation, Soils, Degradation Assessment, Cartographic Modeling, Damietta Governorate, Egypt.
\end{abstract}

\section{Introduction}

As one of the most common and serious environmental problems in the world, land degradation has affected two billion hectares $(22.5 \%)$ of the world's agricultural land, pasture, forest and woodland (Gao and Liu, 2010). Land degradation, defined as a reduction in the biological productivity of land arising from climate change and human activities, is a serious environmental problem (Zhang et $\boldsymbol{a l}$., 2014). It can also be defined as the decline in soil quality caused through its misuse by human (Lal and Stewart, 1990) or a process that describes human induced phenomena, which reduce the current and/ or future soil capability (Ayoub, 1991). It implies long term decline in soil productivity and its environment-moderating capacity (Lal, 2001). The cultivated land represents about $40-50 \%$ of the global (Smith et al., 2007), $20 \%$ of them are severely degraded (Adams and Eswaran, 2000; and Davis and Masten, 2003). In irrigated agriculture lands under the arid climate, water logging and salinization are the major land degradation processes (Dwivedi et al., 1999). Most of these processes are directly affected by human activities (Singh, 1995; and Ali, 2003). Land degradation leads to a gradual decrease in soil productivity (Hillel, 2009), hindering sustainable development (Lal, 2008, and Bockstaller et al., 2009) and consequently food gap is expected (Cassman et al., 2003). The cartographic modeling is an effective technique 
which could be used to simulate a spatial decision making process in the field of agricultural sustainability. It is a set of interacting ordered map operations that act on raw data showing the layers of information starting with the base maps on side and ending with the final product on the other side. In the current, study the cartographic modeling was used to evaluate the land degradation in case of Damietta governorate, Egypt.

\section{Materials and methods}

The Study Area

Damietta governorate is located at the northeast of the Nile Delta between longitudes $31^{\circ} 28^{\circ} \& 32^{\circ}$
$04 `$ and latitude $31^{\circ} 10^{`} \& 31^{\circ} 30^{`}$ (Fig. 1). The governorate covers an area of 227575.32 acres, representing $0.1 \%$ of the Republic's area, and encompasses 4 districts, 10 cities, 47 rural units and 85 villages. According to the preliminary results of 2006 census, population is about 1.1 million people; $38.4 \%$ of them live in urban areas and $61.6 \%$ in rural areas. The population natural growth rate is 21.6 per thousand. The governorate cultivated area covers 108.8 thousand acres and is famous for growing wheat, maize, cotton, rice, potatoes, lemons, grapes, and tomatoes (CAPMAS, 2011).

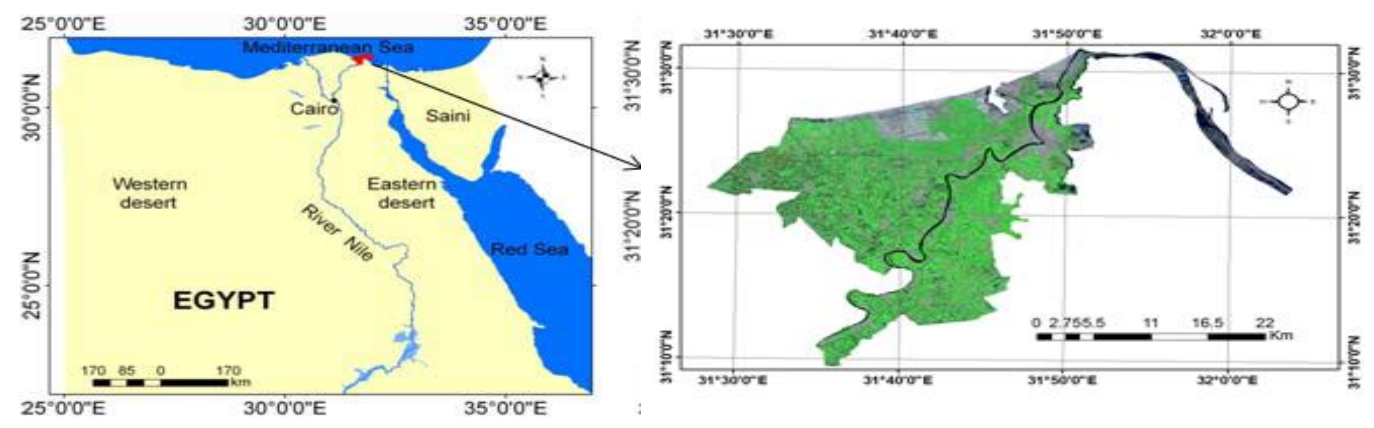

Fig. 1: Location of Damietta Governorate on Egypt Map (to the Left) and Landsat-8 Image of the Governorate acquired in 2013 (to the Right).

\section{Establishing land resources data base:}

Landsat-8 image (path 176, row 038) acquired during the year 2013 was used in this study. Image was radiometrically and geometrically corrected to accurate the irregular sensor response over the image and to correct the geometric distortion due to Earth's rotation (ITT, 2009).

Following the methodology developed by Dobos et al. (2002), the different landforms of the study area were delineated from the satellite image and the digital elevation model extracted from the available contour maps at scale 1:25,000 by Ali and Shalaby (2013). This map was adapted and updated during the field work of this study.

A semi detailed survey was carried out throughout the investigated area in order to gain an appreciation on soil patterns. A total of 18 ground truth sites were studied in the field, from which 18 soil profiles and 36 soil samples were collected to represent the different mapping units (Fig. 2).
Soils samples were analyzed following the procedure detailed by USDA (2004) and Klute (1986) in the National Research Center, Cairo.

The land surveying and laboratory analyses data were recorded in the attribute table of the landform map using Arc-GIS 10.2 software.

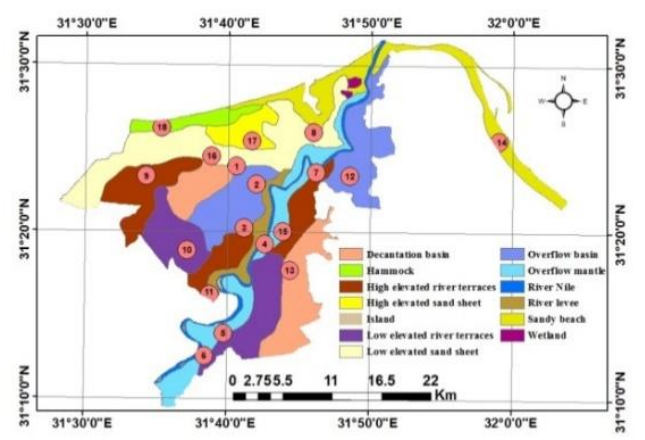

Fig. 2: Locations of Soil Profiles over the Landforms of Damietta Governorate. Modified after Ali and Shalaby (2013).

\section{Digital Mapping of Soil Properties}

Spatial interpolation is commonly used for producing continuous information when data are 
collected at distinct locations (e.g. soil profiles). The inverse distance weighted (IDW) is an interpolation method, which weights the surrounding known values to derive estimations for an unmeasured location. However, the weights are based not only on the distance between the known points and the unmeasured points but also on the overall geostatistical relationships among the known points (Ali and Moghanm, 2013). The inverse distance weighted (IDW) of Arc-GIS 10.2 software has been used to interpolate the soil properties $(\mathrm{pH}$, Electrical Conductivity (EC),
Exchangeable Sodium Percentage (ESP), Cation Exchange Capacity (CEC), and Bulk Density (BD)) over the study area.

\section{Soil Degradation Assessment}

The severity of the processes is characterized by the degree in which the soil is degraded. Hazard or degree (Table 1) were defined and described by using the methodology described by FAO (1979) and UNEP (1991).

Table 1: Rating used to assess the degree of different degradation types

\begin{tabular}{|l|l|l|l|l|l|l|}
\hline \multirow{2}{*}{ Hazard type } & \multirow{2}{*}{ Indicator } & \multirow{2}{*}{ Unit } & \multicolumn{4}{|c|}{ Hazard class } \\
\cline { 4 - 7 } & & & Low & Moderate & High & Very high \\
\hline Salinization & $\mathrm{EC}$ & $\mathrm{dS} / \mathrm{m}$ & $<4$ & $4-8$ & $8-16$ & $>16$ \\
\hline Compaction & Bulk density & $\mathrm{g} / \mathrm{cm}^{3}$ & $<1.2$ & $1.2-1.4$ & $1.4-1.6$ & $>1.6$ \\
\hline Alkalinization & ESP & value & $<10$ & $10-15$ & $15-30$ & $>30$ \\
\hline
\end{tabular}

\section{Cartographic Modelling For Land Degradation Assessment}

The cartographic modeling is an effective technique which could be used to simulate a spatial decision making process in the field of agricultural sustainability. It is a set of interacting ordered map operations that act on raw data showing the layers of information starting with the base maps on side and ending with the final product on the other side. In the current study the guidelines detailed by FAO/UNEP (1979) and UNEP (1991) and cartographic modeling were used to evaluate the agriculture sustainability in case of Damietta governorate, Egypt.

The digital layers of soil salinity, bulk density, ESP and soil depth have been employed to extract the degree of land degradation process over the study area. A simple cartographic model was designed in Arc-GIS 10.2 software where the above mentioned digital layers were the main inputs (Fig.3).

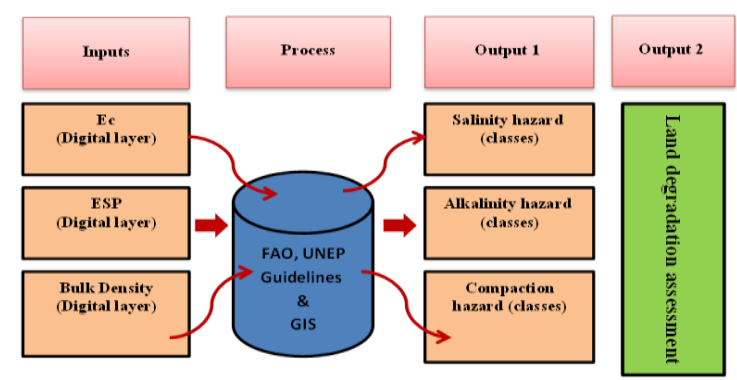

Fig. 3: Simple Cartographic Model used to assess the Land Degradation Hazard

\section{Results and Discussion}

\section{Landforms}

Three landscapes were recognizing in the study area i.e. flood plain, lacustrine plain and marine plain. The flood plain dominates the southern parts including low elevated river terraces, high elevated river terraces, river levee, overflow mantle, decantation basin and overflow basin. Marine plain exhibits the northern parts, comprises the units of high elevated sand sheet, low elevated sand sheet, sandy beach, wetlands and hammock. The landforms of fish ponds and water bodies of the lacustrine plain dominate the northeastern parts of the governorate.

\section{Digital Mapping of Soil Properties}

\section{Surface Soil Layer}

Tables 2, 3 and 4 represent some physical and chemical analyses of the soils in the different landform units. Figures 4, 5, 6, 7 and 8 represent the spatial distribution of $\mathrm{pH}, \mathrm{EC}$, bulk density, exchangeable sodium percentage (ESP) and cation exchange capacity (CEC) in the topsoil layers over the study area. In this study, the data indicated that the soil texture was clayey to sandy; the fine texture attributed the flood plain. Values of soil $\mathrm{pH}$ were slightly alkaline, ranging between 7.4 and 8.63 in the different soils; the highest value characterized the overflow basin. The average $\mathrm{pH}$ value in the surface layers was 8.06. The spatial distribution of EC in the study area indicated that the EC values ranged from 1.8 to $11.39(\mathrm{dS} / \mathrm{m})$ in the surface layer. The average EC value in the surface layers was $3.78(\mathrm{dS} / \mathrm{m})$. The highest value dominated the top soils of high elevated sand 
sheet. The high values of EC may be attributed to the origin of parent material and as a result of high water table (El-Nahry et al., 2008). FAI (1977) suggested that soils with EC value of below 0.80 $(\mathrm{dS} / \mathrm{m})$ are considered normal and suitable for all crop types. The spatial distribution of bulk density (BD) showed that the $\mathrm{BD}$ values ranged from $1.22-1.65\left(\mathrm{~g} / \mathrm{cm}^{3}\right)$; the highest value occupying the surface layers of high elevated sand sheet. The average $\mathrm{BD}$ value in the surface layers was $1.34\left(\mathrm{~g} / \mathrm{cm}^{3}\right)$. The high values of bulk density may be due to the effect of using heavy machinery on the surface layer (Makineci et al., 2007 and Najafi et al., 2009). This result are similar to those of other relevant studies (e.g. El-Nahry et al., 2008; Wahab et al., 2010; Abdel Kawy and Ali, 2012) who studied the spatial distribution of soil properties in soils north of the Nile Delta.

The ESP values ranged between 6.81 and 18.6; the highest value occupying the surface layers of low elevated sand sheet. The average ESP value in the surface layers was 13.97. Mohamed et al. (2007) reported that increasing salinity levels in the irrigation water gradually increased the ESP values of surface and subsurface layers of investigated soils treated with different soil amendments. The spatial distribution of CEC in the study area indicated that the CEC values ranged from 1.61 to 49.9 ( $(\mathrm{cmol}+/ \mathrm{kg}$ soils) in the surface layer. The average CEC value in the surface layers was $21.5(\mathrm{cmol}+/ \mathrm{kg}$ soils $)$. The highest value dominated the topsoils of low elevated river terraces. The CEC of a soil is strongly affected by the amount and type of clay, and amount of organic matter (OM) present in the soil. Both clay and colloidal OM are negatively charged and therefore can act as anions. As a result, these two materials, either individually or combined as a clay-humus complex, have the ability to adsorb and hold positively charged ions (cations). Soils with large amounts of clay and OM have higher CEC than sandy soils low in OM (Tilahun, 2007).

Table 2: Particle Size Distribution of the Studied Soil Profiles

\begin{tabular}{|c|c|c|c|c|c|c|c|}
\hline Profile No. & $\begin{array}{c}\text { depth } \\
\text { (m) }\end{array}$ & $\begin{array}{r}\text { Coarse } \\
\text { sand \% } \\
\end{array}$ & $\begin{array}{c}\text { Fine } \\
\text { sand } \%\end{array}$ & Total sand \% & Silt $\%$ & Clay \% & Texture \\
\hline \multirow{2}{*}{1} & $0-30$ & 4.8 & 16.1 & 20.9 & 38.5 & 40.6 & $\mathrm{C}$ \\
\hline & $30-60$ & 4 & 13.2 & 17.2 & 38.6 & 44.2 & $\mathrm{C}$ \\
\hline \multirow{2}{*}{2} & $0-30$ & 4 & 15.7 & 19.7 & 39 & 41.3 & $\mathrm{C}$ \\
\hline & $30-60$ & 4.6 & 15.3 & 19.9 & 39.5 & 40.6 & $\mathrm{C}$ \\
\hline \multirow{2}{*}{3} & $0-30$ & 4.6 & 16.6 & 21.2 & 39.5 & 39.3 & $\mathrm{CL}$ \\
\hline & $30-60$ & 6 & 20.1 & 26.1 & 37.5 & 36.4 & $\mathrm{CL}$ \\
\hline \multirow{2}{*}{4} & $0-30$ & 3.5 & 16.6 & 20.1 & 40 & 39.9 & $\mathrm{CL}$ \\
\hline & $30-60$ & 5.4 & 16.5 & 21.9 & 39.5 & 38.6 & $\mathrm{CL}$ \\
\hline \multirow{2}{*}{5} & $0-30$ & 5 & 17 & 22 & 39.3 & 38.7 & $\mathrm{CL}$ \\
\hline & $30-60$ & 4.5 & 19.7 & 24.2 & 38.3 & 37.5 & $\mathrm{CL}$ \\
\hline \multirow{2}{*}{6} & $0-30$ & 4 & 15.1 & 19.1 & 38.3 & 42.6 & $\mathrm{CL}$ \\
\hline & $30-60$ & 4.5 & 15.8 & 20.3 & 39.8 & 39.9 & $\mathrm{CL}$ \\
\hline \multirow{2}{*}{7} & $0-30$ & 6 & 17.3 & 23.3 & 38.9 & 37.8 & $\mathrm{CL}$ \\
\hline & $30-60$ & 5 & 15.5 & 20.5 & 39 & 40.5 & $\mathrm{CL}$ \\
\hline \multirow{2}{*}{8} & $0-30$ & 33 & 42.2 & 75.2 & 16.3 & 8.5 & LS \\
\hline & $30-60$ & 42.6 & 46.5 & 89.1 & 7.7 & 3.2 & LS \\
\hline \multirow{2}{*}{9} & $0-25$ & 0.6 & 27.9 & 28.5 & 30.1 & 41.4 & $\mathrm{C}$ \\
\hline & $25-80$ & 0.5 & 35.0 & 35.5 & 21.3 & 43.2 & $\mathrm{C}$ \\
\hline \multirow{2}{*}{10} & $0-30$ & 0.8 & 15.9 & 16.7 & 21.8 & 61.5 & $\mathrm{C}$ \\
\hline & $30-100$ & 0.7 & 15.5 & 16.2 & 31.6 & 52.2 & $\mathrm{C}$ \\
\hline \multirow{2}{*}{11} & $0-35$ & 0.8 & 26.9 & 27.7 & 31.2 & 41.1 & $\mathrm{C}$ \\
\hline & $35-90$ & 0.5 & 20.6 & 21.1 & 34.6 & 44.3 & $\mathrm{C}$ \\
\hline \multirow{2}{*}{12} & $0-25$ & 0.6 & 45.4 & 46 & 31.5 & 22.5 & SCL \\
\hline & $25-70$ & 0.7 & 57.4 & 58.1 & 24.8 & 17.1 & SL \\
\hline \multirow{2}{*}{13} & $0-35$ & 0.3 & 30.9 & 31.2 & 26.3 & 42.5 & $\mathrm{C}$ \\
\hline & $35-80$ & 0.9 & 6.3 & 7.2 & 30.1 & 62.7 & $\mathrm{C}$ \\
\hline \multirow{2}{*}{14} & $0-30$ & 0.3 & 34.7 & 35 & 22.3 & 42.7 & $S$ \\
\hline & $30-75$ & 0.8 & 28.9 & 29.7 & 29.2 & 41.1 & $S$ \\
\hline \multirow{2}{*}{15} & $0-30$ & 0.6 & 21.2 & 21.8 & 34.9 & 43.3 & $\mathrm{C}$ \\
\hline & $30-80$ & 1.1 & 15.1 & 16.2 & 20.2 & 63.6 & $\mathrm{C}$ \\
\hline \multirow{2}{*}{16} & $0-25$ & 4.4 & 92.1 & 96.5 & 1.7 & 1.8 & $S$ \\
\hline & $25-60$ & 3.3 & 94.7 & 98 & 0.7 & 1.3 & $S$ \\
\hline \multirow{2}{*}{17} & $0-20$ & 6.9 & 89.1 & 96 & 2.0 & 2.0 & $S$ \\
\hline & $20-85$ & 7.3 & 89.5 & 96.8 & 1.3 & 1.9 & $S$ \\
\hline
\end{tabular}




\begin{tabular}{|c|c|c|c|c|c|c|c|}
\hline \multirow{2}{*}{18} & $0-30$ & 6.1 & 90.0 & 96.1 & 1.4 & 2.5 & $\mathrm{~S}$ \\
\cline { 2 - 8 } & $30-70$ & 5.4 & 92.0 & 97.4 & 1.0 & 1.6 & $\mathrm{~S}$ \\
\hline
\end{tabular}

Note: $\mathrm{C}=$ Clay, $\mathrm{SCL}=$ Sandy clay loam, $\mathrm{SL}=$ Sandy loam, $\mathrm{S}=$ Sandy, $\mathrm{LS}=$ Loamy Sand

Table 3: Some Chemical Characteristics of the Studied Soil Profiles

\begin{tabular}{|c|c|c|c|c|c|c|c|}
\hline Profile No. & Landform & $\begin{array}{c}\text { depth } \\
\text { (cm) }\end{array}$ & $\begin{array}{c}\text { EC } \\
(1: 1) \\
\mathrm{dSm}^{-1} \\
\end{array}$ & $\begin{array}{c}\text { pH } \\
(1: 2.5)\end{array}$ & $\begin{array}{c}\text { Bulk density } \\
\mathrm{g} / \mathrm{cm}^{3}\end{array}$ & $\begin{array}{c}\text { CEC } \\
\text { cmol+/k } \\
\text { g soils }\end{array}$ & ESP \\
\hline \multirow{2}{*}{1} & \multirow{2}{*}{ Overflow basin } & $0-30$ & 2.18 & 7.99 & 1.24 & 27.65 & 14.7 \\
\hline & & $30-60$ & 2.23 & 8.05 & 1.27 & 29.75 & 14.7 \\
\hline \multirow{2}{*}{2} & \multirow{2}{*}{ Overflow basin } & $0-30$ & 1.9 & 8.22 & 1.26 & 29.9 & 13.1 \\
\hline & & $30-60$ & 2.1 & 8.2 & 1.31 & 25.425 & 14.7 \\
\hline \multirow{2}{*}{3} & \multirow{2}{*}{ Overflow basin } & $0-30$ & 2.67 & 8.63 & 1.33 & 22.425 & 16.45 \\
\hline & & $30-60$ & 3.05 & 8.7 & 1.29 & 21.5 & 15.55 \\
\hline \multirow{2}{*}{4} & \multirow{2}{*}{ Overflow mantle } & $0-30$ & 3.9 & 8.55 & 1.29 & 26.875 & 13 \\
\hline & & $30-60$ & 3.27 & 8.02 & 1.3 & 22.475 & 15.05 \\
\hline \multirow{2}{*}{5} & \multirow{2}{*}{ Overflow mantle } & $0-30$ & 2.57 & 7.66 & 1.28 & 22.3 & 14.9 \\
\hline & & $30-60$ & 2.42 & 7.77 & 1.32 & 21.65 & 15.8 \\
\hline \multirow{2}{*}{6} & \multirow{2}{*}{ Overflow mantle } & $0-30$ & 2.27 & 7.9 & 1.40 & 28.675 & 15.2 \\
\hline & & $30-60$ & 2.42 & 7.93 & 1.27 & 22.45 & 15.85 \\
\hline \multirow{2}{*}{7} & \multirow{2}{*}{ High elevated river terraces } & $0-30$ & 3 & 7.64 & 1.27 & 21.575 & 16.6 \\
\hline & & $30-60$ & 2.15 & 7.7 & 1.27 & 27.275 & 17.7 \\
\hline \multirow{2}{*}{8} & \multirow[t]{2}{*}{ Low elevated sand sheet } & $0-30$ & 1.85 & 8.3 & 1.36 & 6.5 & 18.6 \\
\hline & & $30-60$ & 1.35 & 8.36 & 1.52 & 4.875 & 19.6 \\
\hline \multirow{2}{*}{9} & \multirow{2}{*}{ High elevated river terraces } & $0-25$ & 3.1 & 8.1 & 1.26 & 30.4 & 14.7 \\
\hline & & $25-80$ & 3.8 & 8.1 & 1.29 & 32.2 & 14.8 \\
\hline \multirow{2}{*}{10} & \multirow{2}{*}{ Low elevated river terraces } & $0-30$ & 5.4 & 8.1 & 1.26 & 49.9 & 14.7 \\
\hline & & $30-100$ & 5.9 & 8.1 & 1.24 & 38.7 & 15 \\
\hline \multirow{2}{*}{11} & \multirow{2}{*}{ River levee } & $0-35$ & 3.9 & 8.1 & 1.28 & 28.7 & 14.9 \\
\hline & & $35-90$ & 3.8 & 8.1 & 1.31 & 35.2 & 14.7 \\
\hline \multirow{2}{*}{12} & \multirow{2}{*}{ Overflow basin } & $0-25$ & 2.1 & 7.4 & 1.39 & 23.2 & 11 \\
\hline & & $25-70$ & 3.2 & 7.5 & 1.37 & 19.8 & 9.8 \\
\hline \multirow{2}{*}{13} & \multirow{2}{*}{ Decantation basin } & $0-35$ & 7.4 & 8.2 & 1.22 & 29.8 & 15.9 \\
\hline & & $35-80$ & 6.8 & 8.1 & 1.24 & 44.3 & 19.8 \\
\hline \multirow{2}{*}{14} & & $0-30$ & 6.1 & 8.4 & 1.32 & 2.8 & 16 \\
\hline & Sandy beach & $30-75$ & 3.2 & 8.5 & 1.33 & 2.2 & 20.5 \\
\hline & & $0-30$ & 2.3 & 8.5 & 1.26 & 30.2 & 17.9 \\
\hline 15 & Overflow mantle & $30-80$ & 1.4 & 8.6 & 1.21 & 49.8 & 19.5 \\
\hline & & $0-25$ & 4.2 & 7.9 & 1.58 & 2.3 & 6.8 \\
\hline 16 & Low elevated sand sheet & $25-60$ & 6.2 & 7.9 & 1.57 & 2.5 & 8.6 \\
\hline 17 & High eleyated cand sheet & $0-20$ & 11.4 & 7.6 & 1.65 & 1.6 & 9.8 \\
\hline 17 & High elevated sand sheet & $20-85$ & 20.6 & 7.7 & 1.6 & 2.7 & 9.5 \\
\hline & & $0-30$ & 1.8 & 7.9 & 1.54 & 2.4 & 7.2 \\
\hline 18 & Hammock & $30-70$ & 2.3 & 8.0 & 1.6 & 4.6 & 6.7 \\
\hline
\end{tabular}

Table 4: Summary Statistics of Some Soil Properties

\begin{tabular}{|c|c|c|c|c|c|c|}
\hline \multicolumn{7}{|l|}{ Soil } \\
\hline Depth & \multicolumn{3}{|c|}{ Top soil $(0-30 \mathrm{~cm})$} & \multicolumn{3}{|c|}{ Subsoil $(30-60 \mathrm{~cm})$} \\
\hline Parameters & Mean & Min. & Max. & Mean & Min. & Max. \\
\hline $\mathrm{EC} \mathrm{dSm}{ }^{-1}$ & 3.78 & 1.8 & 11.39 & 4.23 & 1.35 & 20.59 \\
\hline Bulk density $\mathrm{g} / \mathrm{cm}^{3}$ & 1.34 & 1.22 & 1.65 & 1.35 & 1.21 & 1.60 \\
\hline pH & 8.06 & 7.4 & 8.63 & 8.07 & 7.5 & 8.7 \\
\hline CEC cmol+/kg soils & 21.5 & 1.61 & 49.9 & 22.6 & 2.2 & 49.8 \\
\hline ESP & 13.97 & 6.8 & 18.6 & 14.88 & 6.7 & 20.5 \\
\hline
\end{tabular}




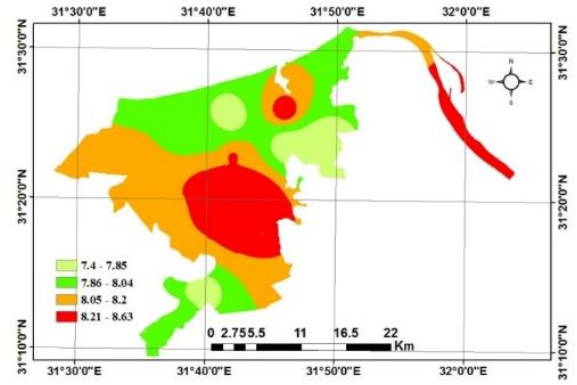

Fig. 4: Spatial Distribution of $\mathrm{pH}$ in the Surface Soil Layer

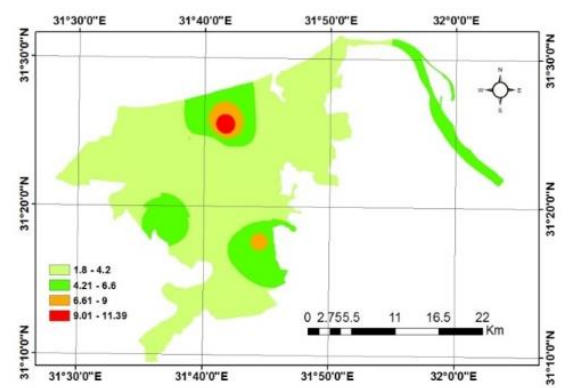

Fig. 5: Spatial Distribution of EC in the Surface Soil Layer

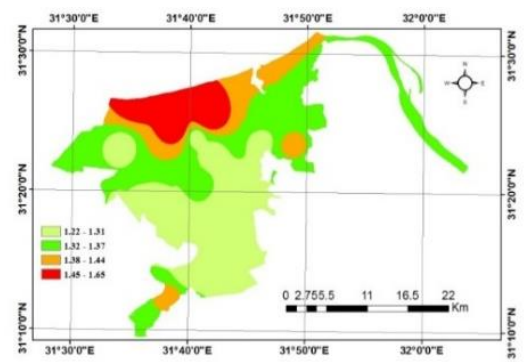

Fig.6: Spatial Distribution of Bulk Density in the Surface Soil Layer

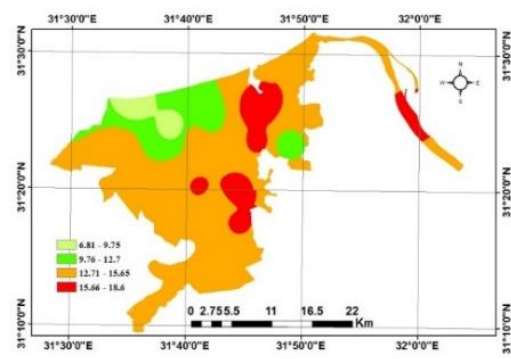

Fig. 7: Spatial Distribution of ESP in the Surface Soil Layer

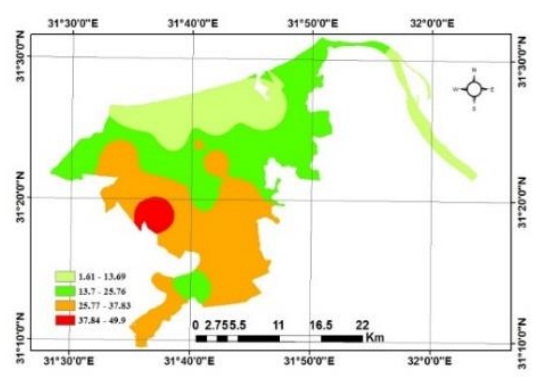

Fig. 8: Spatial Distribution of CEC in the Surface Soil Layer

\section{Subsurface Soil Layer}

Figures 9, 10, 11, 12 and 13 represent the spatial distribution of $\mathrm{pH}, \mathrm{EC}$, bulk density, ESP and CEC in the subsurface layers over the study area. The data indicated that the soil texture was clayey to sandy; the fine texture attributed the flood plain. Values of soil $\mathrm{pH}$ were slightly alkaline, ranging between 7.5 and 8.7 in the different soils; the lowest value characterized the overflow basin. The average $\mathrm{pH}$ value in the subsurface layers was 8.07. The spatial distribution of EC in the study area indicated that the EC values ranged from 1.35 to $20.58(\mathrm{dS} / \mathrm{m})$ in the subsurface layer. The results showed that the lowest value of soil EC $(1.35(\mathrm{dS} / \mathrm{m}))$ was in low elevated sand sheet, while the highest one $(20.58(\mathrm{dS} / \mathrm{m}))$ was observed in the high elevated sand sheet. The average EC value in the subsurface layers was $4.23(\mathrm{dS} / \mathrm{m})$. This is in an agreement with Berhe et al., 2013 who found that the average EC value in the subsurface layers was higher than the average EC value in the surface layers. The high values of EC may be attributed to over- irrigation and other forms of poor agricultural and soil management practices (Tanton et al., 1998).

The spatial distribution of bulk density (BD) showed that the BD values ranged from 1.21-1.60 $\left(\mathrm{g} / \mathrm{cm}^{3}\right)$; the high values occupying the subsurface layers of hammock and the high elevated sand sheet. The average BD value in the subsurface layers was $1.35\left(\mathrm{~g} / \mathrm{cm}^{3}\right)$. This is in an agreement with Singh et al., 2009 who found that the average of $\mathrm{BD}$ values in the subsurface layers was higher than the average BD values in the surface layers. The increase in bulk density with depth is due to migration of silt and clay from upper layers to this layer, which resulted in firm packing (consolidation) of soil (Adachi, 1992).

The ESP values ranged between 6.7 and 20.5; the highest value occupying the subsurface layers of sandy beach. The average ESP value in the subsurface layers was 14.88. This is in an agreement with Boulos et al., 2009 who found that ESP was lower in the soil surface than the other deeper layers and decreased after one year of leaching process due to the effect of highly ground water salinity. The spatial distribution of CEC in the study area indicated that the CEC values ranged from 2.2 to 49.79 (cmol $+/ \mathrm{kg}$ soils) in the subsurface layer. The highest value dominated the soils of overflow mantle. The high values are due to the majority of clay contents in the soil texture (Boulos et al., 2009). 


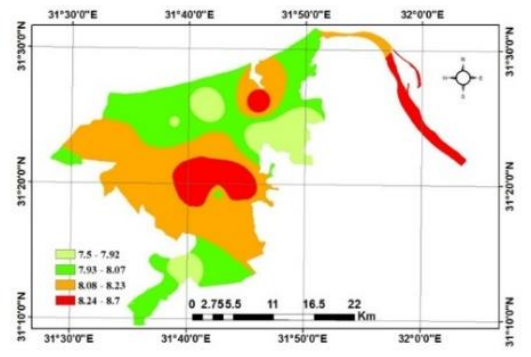

Fig. 9: Spatial Distribution of $\mathrm{pH}$ in the Subsurface Soil Layer

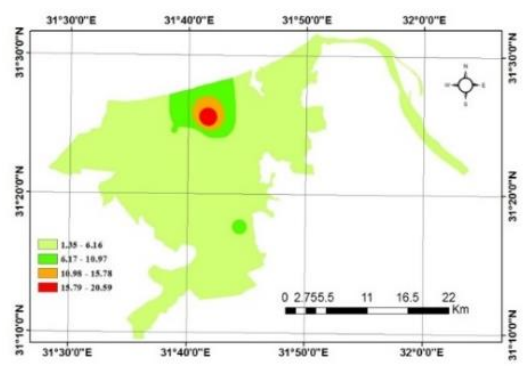

Fig. 10: Spatial Distribution of EC in the Subsurface Soil Layer

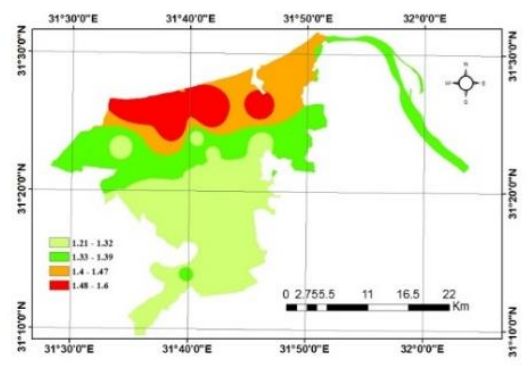

Fig. 11: Spatial Distribution of Bulk Density in the Subsurface Soil Layer

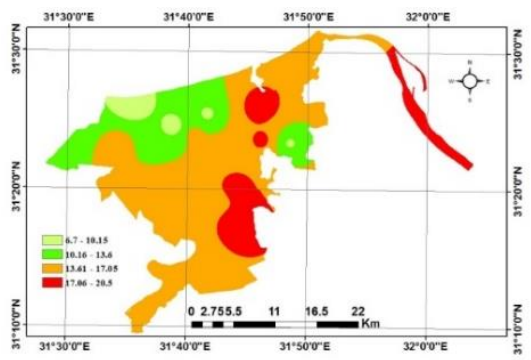

Fig. 12: Spatial Distribution of ESP in the Subsurface Soil Layer

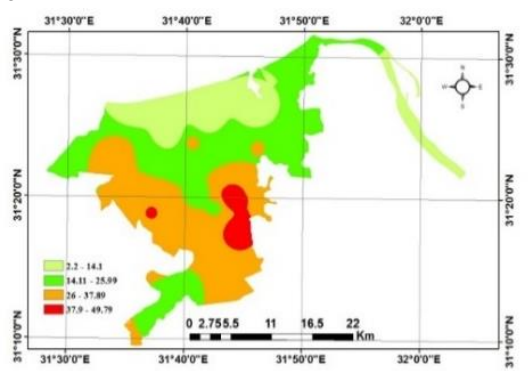

Fig. 13: Spatial Distribution of CEC in the Subsurface Soil Layer

\section{Cartographic Modeling for Land Degradation Assessment}

\section{Digital Layers (Inputs)}

\section{1- Soil Salinity}

Figure 4 represents the spatial distribution of soil salinity; the given data indicated that the EC differ from 1.8 to $11.39(\mathrm{dS} / \mathrm{m})$. The high values are concentrated to the north of the study area as it closed to the Mediterranean Sea. The hazard class of soil salinity differs from low to high. The high salinity hazard characterizes the soils of high elevated sand sheet which represented by soil profile no. 17.

\section{2- Compaction}

Figure 5 represents the spatial distribution of soil compaction; the given data indicated that the BD differs from $1.22-1.65\left(\mathrm{~g} / \mathrm{cm}^{3}\right)$; the high values are concentrated to the north of the study area as it closed to the Mediterranean Sea. The hazard class of soil compaction differs from moderate to very high. The high compaction hazard characterizes the soils of high elevated sand sheet which represented by soil profile no. 17 .

\section{3- Soil Alkalinity}

Figure 6 represents the spatial distribution of soil alkalinity; the given data indicated that the ESP differs from 6.81 and 18.6. The hazard class of soil alkalinity differs from low to high. The high alkalinity hazard characterizes the soils of low elevated sand sheet which represented by soil profile no. 8 .

\section{Classes Of Soil Degradation Hazard}

\section{Surface Layer}

Table 5 and Figs. 14, 15 and 16 represent the soil degradation hazard classes in the surface soil layers of the study area. The obtained data reveals that the soils have a low to high risk of chemical degradation (i.e. salinization and alkalinization) and moderate to very high risk of physical degradation (soil compaction). The high risk of chemical degradation (i.e. salinization and alkalinization) and physical degradation (soil compaction) cover an area of $276.24 \mathrm{~km}^{2}$ and $84.51 \mathrm{~km}^{2}$, respectively.

Subsurface Layer

Table 6 and Figs. 17, 18 and 19 represent the soil degradation hazard classes in the subsurface soil layers of the study area. The obtained data reveals that the subsurface soils are subjected toa low to very high risk of chemical degradation ((i.e. salinization and alkalinization) and a moderate to high risk of physical degradation (soil 
compaction). The high risk of chemical degradation ((i.e. salinization and alkalinization) and physical degradation (soil compaction) cover an area of $459.03 \mathrm{~km}^{2}$ and $125.54 \mathrm{~km}^{2}$, respectively.

Table 5: Area of Soil Degradation Hazard Classes in the Surface Soil Layer

\begin{tabular}{|c|c|c|c|}
\hline Hazard type & $\begin{array}{c}\text { Hazard } \\
\text { class }\end{array}$ & $\begin{array}{c}\text { Area } \\
\left(\mathbf{K m}^{\mathbf{2}} \mathbf{)}\right.\end{array}$ & $\begin{array}{c}\text { Percentage } \\
\text { of the total } \\
\text { area (\%) }\end{array}$ \\
\hline \multirow{4}{*}{ Salinization } & Low & 459.09 & 69.70 \\
\cline { 2 - 4 } & Moderate & 197.33 & 29.96 \\
\cline { 2 - 4 } & High & 2.24 & 0.34 \\
\cline { 2 - 4 } & Very high & - & - \\
\hline \multirow{4}{*}{ Alkalinization } & Low & 15.02 & 2.28 \\
\cline { 2 - 4 } & Moderate & 369.64 & 56.12 \\
\cline { 2 - 4 } & High & 274 & 41.6 \\
\cline { 2 - 4 } & Very high & - & \\
\hline \multirow{4}{*}{ Compaction } & Low & - & - \\
\cline { 2 - 4 } & Moderate & 574.15 & 87.17 \\
\cline { 2 - 4 } & High & 83.85 & 12,73 \\
\cline { 2 - 4 } & Very high & 0.66 & 0.1 \\
\hline & Total & $\mathbf{6 5 8 . 6 6}$ & $\mathbf{1 0 0}$ \\
\hline
\end{tabular}

Table 6: Area of Soil Degradation Hazard Classes in the Subsurface Soil Samples

\begin{tabular}{|c|c|c|c|}
\hline \multirow{4}{*}{ Hazard type } & $\begin{array}{c}\text { Hazard } \\
\text { class }\end{array}$ & $\begin{array}{c}\text { Area } \\
\mathbf{( K m}^{\mathbf{2}} \mathbf{)}\end{array}$ & $\begin{array}{c}\text { Percentage } \\
\text { of the total } \\
\text { area }(\mathbf{\%})\end{array}$ \\
\hline \multirow{4}{*}{ Salinization } & Low & 466.46 & 70.82 \\
\cline { 2 - 4 } & Moderate & 181.79 & 27.60 \\
\cline { 2 - 4 } & High & 9.22 & 1.4 \\
\cline { 2 - 4 } & Very high & 1.19 & 0.18 \\
\hline & Low & 11.46 & 1.74 \\
\cline { 2 - 4 } Alkalinization & Moderate & 198.58 & 30.15 \\
\cline { 2 - 4 } & High & 448.62 & 68.11 \\
\cline { 2 - 4 } & Very high & - & - \\
\hline & Low & - & - \\
\cline { 2 - 4 } & Moderate & 533.12 & 80.94 \\
\cline { 2 - 4 } & High & 125.54 & 19.06 \\
\cline { 2 - 4 } & Very high & - & - \\
\hline & Total & $\mathbf{6 5 8 . 6 6}$ & $\mathbf{1 0 0}$ \\
\hline
\end{tabular}

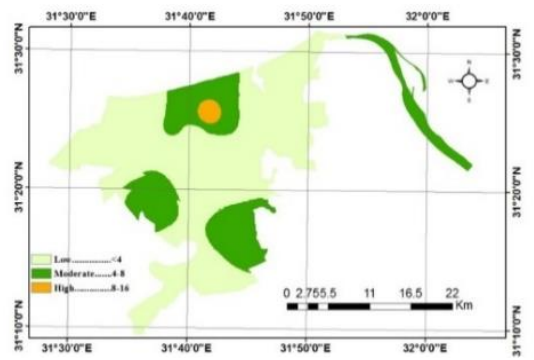

Fig. 14: Classes of Soil Degradation Hazard (Salinization) in the Surface Soil Layer

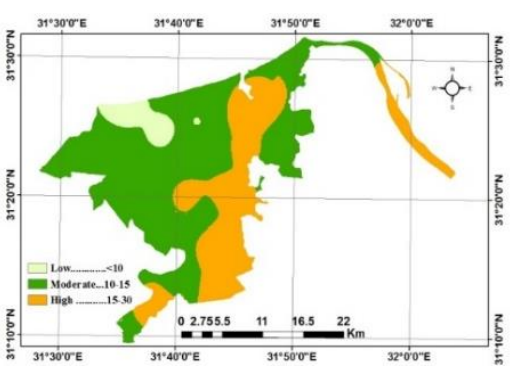

Fig. 15: Classes of Soil Degradation Hazard (Alkalinization) in the Surface Soil Layer

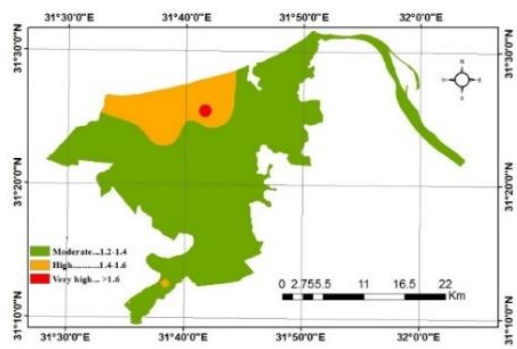

Fig. 16: Classes of Soil Degradation Hazard (Compaction) in the Surface Soil Layer

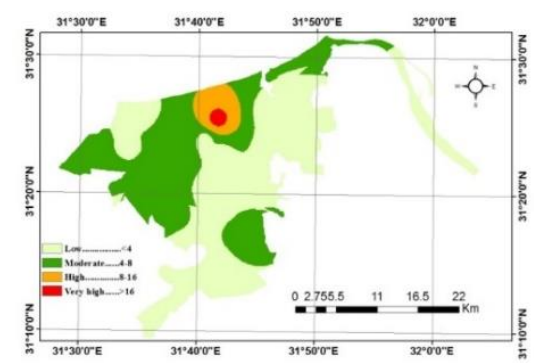

Fig. 17: Classes of Soil Degradation Hazard (Salinization) in the Subsurface Soil Layer

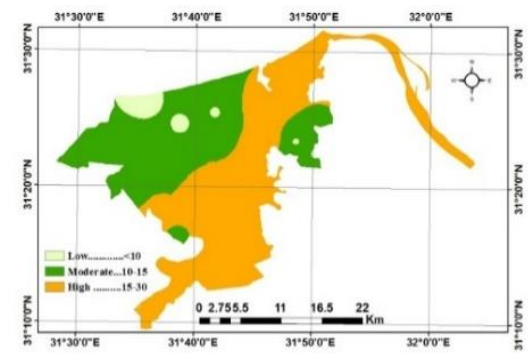

Fig. 18: Classes of Soil Degradation Hazard (Alkalinization) in the Subsurface Soil Layer

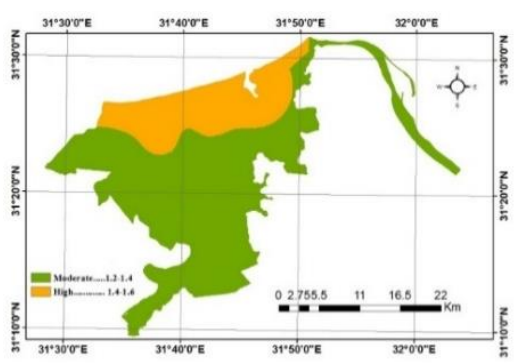

Fig. 19: Classes of Soil Degradation Hazard (Compaction) in the Subsurface Soil Layer 


\section{Degradation Hazard}

The overall degradation hazard has been extracted from the status of soil salinity, alkalinity and compaction in each soil profile. The data indicated that profiles 1 which represents the soils of overflow basin is characterized by low salinity $(\mathrm{EC}=2.18 \mathrm{dS} / \mathrm{m})$, moderate compaction $(\mathrm{BD}=$ $\left.1.24 \mathrm{~g} / \mathrm{cm}^{3}\right)$ and moderate alkalinity $(\mathrm{ESP}<15)$. In general, the main degradation hazards in this profile are compaction and alkalinity. In profile 2 which represents the soils of overflow basin is characterized by low salinity $(\mathrm{EC}=1.9 \mathrm{dS} / \mathrm{m})$, moderate compaction $\left(\mathrm{BD}=1.26 \mathrm{~g} / \mathrm{cm}^{3}\right)$ and moderate alkalinity (ESP< 15).In general, the main degradation hazards in this profile are compaction and alkalinity. In profile 3 which represents the soils of overflow basin is characterized by low salinity $(\mathrm{EC}=2.67 \mathrm{dS} / \mathrm{m})$, moderate compaction $\left(\mathrm{BD}=1.33 \mathrm{~g} / \mathrm{cm}^{3}\right)$ and high alkalinity (ESP 15-30).In general, the main degradation hazard in this profile is alkalinity. In profile 4 which represents the soils of overflow mantle is characterized by low salinity $(\mathrm{EC}=3.9$ $\mathrm{dS} / \mathrm{m})$, moderate compaction $\left(\mathrm{BD}=1.29 \mathrm{~g} / \mathrm{cm}^{3}\right)$ and moderate alkalinity (ESP < 15). In general the main degradation hazards in this profile are compaction and alkalinity. In profile 5 which represents the soils of overflow mantle is characterized by low salinity $(\mathrm{EC}=2.57 \mathrm{dS} / \mathrm{m})$, moderate compaction $\left(\mathrm{BD}=1.28 \mathrm{~g} / \mathrm{cm}^{3}\right)$ and moderate alkalinity (ESP < 15). In general, the main degradation hazards in this profile are compaction and alkalinity. In profile 6 which represents the soils of overflow mantle is characterized by low salinity $(\mathrm{EC}=2.27 \mathrm{dS} / \mathrm{m})$, high compaction $\left(\mathrm{BD}=1.40 \mathrm{~g} / \mathrm{cm}^{3}\right)$ and high alkalinity (ESP 15-30). In general, the main degradation hazards in this profile are compaction and alkalinity. In profile 7 which represents the soils of high elevated river terraces is characterized by low salinity $(\mathrm{EC}=3 \mathrm{dS} / \mathrm{m})$, moderate compaction $\left(\mathrm{BD}=1.27 \mathrm{~g} / \mathrm{cm}^{3}\right)$ and high alkalinity (ESP 15-30). In general, the main degradation hazard in this profile is alkalinity. In profile 8 which represents the soils of low elevated sand sheet is characterized by low salinity $(\mathrm{EC}=$ $1.85 \mathrm{dS} / \mathrm{m})$, moderate compaction $(\mathrm{BD}=$ $1.36 \mathrm{~g} / \mathrm{cm}^{3}$ ) and high alkalinity (ESP 15-30). In general ,the main degradation hazard in this profile is alkalinity. In profile 9 which represents the soils of high elevated river terraces is characterized by low salinity $(\mathrm{EC}=3.1 \mathrm{dS} / \mathrm{m})$, moderate compaction $\left(\mathrm{BD}=1.26 \mathrm{~g} / \mathrm{cm}^{3}\right)$ and moderate alkalinity (ESP < 15). In general, the main degradation hazards in this profile are compaction and alkalinity. In profile 10 which represents the soils of low elevated river terraces is characterized by moderate salinity $(\mathrm{EC}=$ $5.4 \mathrm{dS} / \mathrm{m})$, moderate compaction $\left(\mathrm{BD}=1.26 \mathrm{~g} / \mathrm{cm}^{3}\right)$ and moderate alkalinity (ESP $<15)$. In general, the main degradation hazards in this profile are salinity, compaction and alkalinity. In profile 11 which represents the soils of river levee is characterized by low salinity $(\mathrm{EC}=3.9 \mathrm{dS} / \mathrm{m})$, moderate compaction $\left(\mathrm{BD}=1.28 \mathrm{~g} / \mathrm{cm}^{3}\right)$ and moderate alkalinity (ESP < 15).In general, the main degradation hazards in this profile are compaction and alkalinity. In profile 12 which represents the soils of overflow basin is characterized by low salinity $(\mathrm{EC}=2.1 \mathrm{dS} / \mathrm{m})$, moderate compaction $\left(\mathrm{BD}=1.39 \mathrm{~g} / \mathrm{cm}^{3}\right)$ and moderate alkalinity (ESP < 15). In general, the main degradation hazards in this profile are compaction and alkalinity.In profile 13 which represents the soils of decantation basin is characterized by moderate salinity $(\mathrm{EC}=$ $7.4 \mathrm{dS} / \mathrm{m})$, moderate compaction $\left(\mathrm{BD}=1.22 \mathrm{~g} / \mathrm{cm}^{3}\right)$ and high alkalinity (ESP 15-30). In general, the main degradation hazard in this profile is alkalinity. In profile 14 which represents the soils of sandy beach is characterized by moderate salinity $(\mathrm{EC}=6.1 \mathrm{dS} / \mathrm{m})$, moderate compaction $\left(\mathrm{BD}=1.32 \mathrm{~g} / \mathrm{cm}^{3}\right)$ and high alkalinity (ESP 1530). In general the main degradation hazard in this profile is alkalinity. In profile 15 which represents the soils of overflow mantle is characterized by low salinity $(\mathrm{EC}=2.3 \mathrm{dS} / \mathrm{m})$, moderate compaction $\left(\mathrm{BD}=1.26 \mathrm{~g} / \mathrm{cm}^{3}\right)$ and high alkalinity (ESP 15-30). In general, the main degradation hazard in this profile is alkalinity. In profile 16 which represents the soils of low elevated sand sheet is characterized by moderate salinity $(\mathrm{EC}=$ $4.2 \mathrm{dS} / \mathrm{m})$, high compaction $\left(\mathrm{BD}=1.58 \mathrm{~g} / \mathrm{cm}^{3}\right)$ and low alkalinity (ESP <10). In general, the main degradation hazard in this profile is compaction. In profile 17 which represents the soils of high elevated sand sheet is characterized by high salinity $(\mathrm{EC}=11.4 \mathrm{dS} / \mathrm{m})$, very high compaction $\left(\mathrm{BD}=1.65 \mathrm{~g} / \mathrm{cm}^{3}\right)$ and low alkalinity $(\mathrm{ESP}<10) . \mathrm{In}$ general, the main degradation hazard in this profile is compaction. In profile 18 which represents the soils of hammock is characterized by low salinity $(\mathrm{EC}=1.8 \mathrm{dS} / \mathrm{m})$, high compaction $\left(\mathrm{BD}=1.54 \mathrm{~g} / \mathrm{cm}^{3}\right)$ and low alkalinity (ESP <10).In general, the main degradation hazard in this profile is compaction. 


\section{Digital Layers (Output)}

Table 7 and Fig.20 represents the degradation hazard classes extracted from cartographic modelling. The area is classified into two classes: low and high degradation hazard. The high degraded areas are threatened by high alkalinity, salinity and compaction hazards and cover an area of $177.58 \mathrm{~km}^{2}(26.6 \%)$. The low degraded areas are subjected to low alkalinity, salinity and compaction hazards and cover an area of 489.58 $\mathrm{km}^{2}(73.4 \%)$. of the total area. The results indicated that a significant area of the governorate is threatened by high degradation hazard.

Table 7: Area of Degradation Hazard Classes Extracted from Cartographic Modelling

\begin{tabular}{|c|c|c|}
\hline $\begin{array}{c}\text { Hazard } \\
\text { class }\end{array}$ & $\begin{array}{c}\text { Area } \\
\left(\mathbf{K m}^{\mathbf{2}}\right)\end{array}$ & $\begin{array}{c}\text { Percentage of the total } \\
\text { area }(\mathbf{\%})\end{array}$ \\
\hline Low & 489.58 & 73.4 \\
\hline High & 177.58 & 26.6 \\
\hline & Total & $\mathbf{6 6 7 . 1 5}$ \\
\hline
\end{tabular}

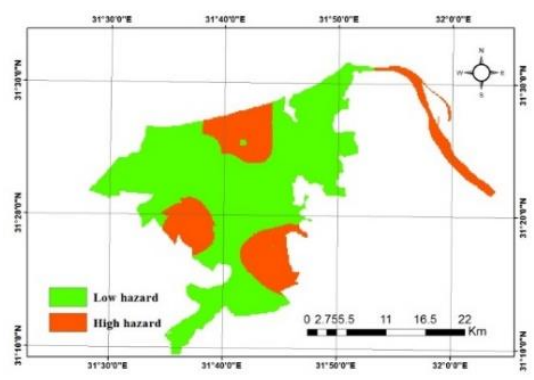

Fig. 20: Classes of Degradation Hazard extracted from Cartographic Modelling

\section{Conclusion and Recommendations}

Understanding the spatial distribution of soil properties and their relation with the landforms is the key to setting the appropriate land management. Distribution of the soil properties over the landforms of Damietta governorate have been investigated by using spatial analyses techniques. The area includes various landforms i.e. flood plain, lacustrine plain and marine plain. The distribution of the soil properties i.e. $\mathrm{pH}, \mathrm{EC}$ and bulk density (BD) represents a wide variation over these landforms. It can be concluded that a significant area in the governorate is subjected to a high risk of physical (soil compaction) and chemical degradation (salinization). Moreover, processes of soil compaction and soil salinity are low to high in different land units. GIS is very helpful tool to store, manipulate and quantitatively evaluate soil degradation.
The following recommendations suggested for reducing land degradation in the governorate:

- Establish methods to remedy any degraded land prior to agricultural or residential use (i.e. salinity, erosion, leeching, stagnation, chemical composition, etc.).

- Reducing soil compaction could be realized through avoiding field practices that have the potential to damage the soil structure. So, conducting field operations with heavy machines on wet soils should be minimized.

- Governments should form committees to promote sustainable land use practices.

- Introduce the concept of a controlled environmental greenhouse as an option/alternative to farms whose land easily suffers from land degradation.

- Revert to such agricultural practices as crop rotation in order to preserve soil quality.

- Move to drip irrigation methods to maintain soil quality.

- Use minimum / conservation tillage methods.

- Use precision agricultural methods.

- Promoting land-use systems that provide permanent vegetative cover to protect the soil, increase fertility and optimize water penetration.

- Identifying the causes of land degradation before prescribing solutions for it.

- Before developing land, a clear evaluation procedure should be established and implemented.

- The government should pass legislation that protects land against practices that lead to degradation

- Establish community environmental awareness programs.

- Decisions regarding land use should be based on continual research and monitoring on the condition and stability of the land.

- Informational meetings regarding the impact of land use on the environment should be held periodically within the community

- Educate the people about respecting the land and use of sustainable land practices.

- Using techniques that provide economic benefits for land users in the short as well as the long term.

- Develop a long-term land conservation plan.

- Provide data on land resources - including soils, climate, vegetation and topography if land-use and conservation policies are to be developed.

- Evaluating land resources and identifying the causes of land misuse. 


\section{References}

Abdel Kawy, W. and Ali, R. (2012). Assessment of Soil Degradation and Resilience at Northeast Nile Delta, Egypt: The Impact on Soil Productivity. Egypt. J. Remote Sens. Space Sci.; 15(1): 19-30.

Adachi, K. (1992). Effect of Puddling on Rice Soil Physics: Softness of Puddled Soil and Percolation. In: Murty, V.V.N., Koga K. (Eds.). Soil and Water Engineering For Paddy Field Management. Proceedings of the International Workshop on Soil and Water Engineering For Paddy Field Management. Asian Institute of Technology, Bangkok: 220-231

Adams, C.R. and Eswaran, H. (2000). Global Land Resources in the Context of Food and Environmental Security: 35-50. In: Gawande SP, eds. Advances in Land Resources Management for the 20th Century. New Delhi: Soil Conservation Society of India. $655 \mathrm{p}$.

Ali, R.R. (2003). Evaluation of Land Degradation of Some Areas in Middle and North Nile Delta, Egypt. PhD thesis, Fac. Agric., Cairo Unvi., 224p.

Ali, R. R., and Shalaby, A. (2013). The Use of Cartographic Modeling for the Assessment of Agricultural Sustainability of Damietta Governorate, Egypt; J. Appl. Sci. Res.; 9 (1): 248257.

Ali, R.R. and Moghanm, F.S. (2013). Variation of Soil Properties over the Landforms around Idku Lake, Egypt. J. Remote Sens. and Space Sci., 16: 91-101.

Ayoub, A. T. (1991). An Assessment of Human Induced Soil Degradation in Africa. U. N. environmental program, Nairobi, Kenya. Second soil Sci. conf. Cairo Egypt.

Berhe, H.; Anjulo, A.; Abdelkadir, A. and Edwards, S.(2013).Evaluation of the Effect of Ficus thonningii (Blume) on Soil Physicochemical Properties in Ahferom District of Tigray, Ethiopia, J. Soil Sci. Environ. Manage;4(2): 35-45.

Bockstaller, C.; Guichard, L.; Keichinger, O.; Girardin, P.; Galan, M.B. and Gaillard, G. (2009). Comparison of Methods to assess the Sustainability of Agricultural Systems, A Review. Agron. Sustain. Dev., 29: 223-235.

Boulos, M. M.; Ghazy, A.I. and Behairy, S.S. (2009). Drainage Effect on Salinity in Clayey Soil at ElHusseinia Plan, Misr J. Ag. Eng., 25(3): 861-882

CAPMAS, (2011). Mobilization and Statistic of Damietta Governorate. Central Agency for Public Mobilization and Statistics (CAPMAS) Cairo, Egypt.

Cassman, K.G.; Dobermann, A.; Walters, D.T. and Yang, H. (2003). Meeting Cereal Demand While Protecting Natural Resources and Improving Environmental Quality, Ann. Rev. Environ. Res., 28: $315-358$.
Davis, M.L. and Masten, S.J. (2003). Principles of Environmental Engineering and Science, McGrawHill Professional, New York.

Dwivedi, R. S.; Sreenivas, K.; and Ramana, K. V. (1999). Inventory of Salt Affected Soils and Water Logged Areas: a Remote Sensing Approach; Int. J. Remote Sens.; 20: 8, 1589-1599.

Dobos, E.; Norman, B.; Bruee, W.; Luca, M.; Chris, J. and Erika, M. (2002). The Use of DEM and Satellite Images for Regional Scale Soil Database. In: Proceedings of the 17th World Congress of Soil Science, August 14-21, 2002, Bangkok, Thailand.

El-Nahry, A.H; Ibrahiem, M.M. and El-Baroudy, A.A. (2008). Assessment of Soil Degradation in the Northern Part of Nile Delta, Egypt, using remote sensing and GIS techniques. Egypt. J. Remote Sensing \& Space Sci., 11:139-154.

FAI (1977). Hand Book of Fertilizer Usage. Fertilizer Association of India, New Delhi. India.

FAO. (1979). A Provisional Methodology for Soil Degradation Assessment. FAO, Rome, Italy.

FAO/UNEP (1979). A Provisional Methodology for Degradation Assessment” PP, 48. Rome, FAO.

Gao, J. and Liu, Y. (2010). Determination of Land Degradation Causes in Tongyu County, Northeast China via Land Cover Change Detection, Int. J. Appl. Earth Obs. Geoinf. 12(1): 9-16.

Hillel, D. (2009). The Mission of Soil Science in a Changing World, J. Plant Nutr. Soil Sci., 172: 5-9.

ITT (2009). ITT Corporation ENVI 4.7 Software, 1133 Westchester Avenue, White Plains, NY 10604, USA.

Klute, A. (1986). Water Retention: Laboratory Methods: 635-662. In A. Klute (ed.) Methods of Soil Analysis. Part 1and 2nd ed. Agron. Monogr. 9. ASA and SSSA, Madison, WI.

Lal, R. (2001). Soil Degradation by Erosion. Land Degrad. Dev.; 12(6): 519-539

Lal, R. (2008). Soils and Sustainable Agriculture, a Review. Agron. Sustain. Dev., 28: 57-64.

Lal, R. and Stewart, B.A. (1990). Advances in Soil Science, soil Degradation, New York: Springer Verlag, 349 P.

Makineci, E; Demir, M. and Yilmaz, E. (2007). Longterm harvesting effects on skid road in a fir (Abies bornmulleriana Mattf) plantation forest. Build Environ 42:1538-1543.

Mohamed, A. I.; Ali, O. M. and Matloub, M. A.(2007). Effect of Soil Amendments on Some Physical and Chemical Properties of Some Soils of Egypt under Saline Irrigation Water, African Crop Sci. Conference Proceedings; 8: 1571-1578.

Najafi, A.; Solgi, A. and Sadeghi, S.H.R. (2009). Effect of ground skid $\neg$ ding and skid trail slope on soil disturbance. Soil Till Res 103:165-169. 
Singh, K. B.; Jalota, S. K. and Sharma, B. D. (2009). Effect of Continuous Rice-Wheat Rotation on Soil Properties from Four Agro-Ecosystems of Indian Punjab. Communications in Soil Sci. and Plant Analysis 40:2945-2958

Singh, S. (1995). Desert Spread and Desertification: Some Basic Issues. Ann. arid zone, 24(2): 87-98.

Smith, P.; Martino, D.; Cai, Z.; Gwary, D.; Janzen, H.; Kumar, P.; McCarl, B.; Ogle, S.; Mara, F.O.; Rice, C.; Scholes, B. and Sirotenko, O. ( 2007). Agriculture. In Climate Change 2007: Mitigation. Contribution of Working Group III to the Fourth Assessment Report of the Intergovernmental Panel on Climate Change [B. Metz, O.R. Davidson, P.R. Bosch, R. Dave, L.A. Meyer (eds)], Cambridge University Press, Cambridge, United Kingdom and New York, NY, USA.

Tanton, T.W; Anstrong, A.S.B and Wilkinson, F.M. (1998). The Leaching of Salts from Saline Clay Soils. Factors Affecting the Leaching Process. Soil Use and Manage. ; 4: 133-144.
Tilahun, G. (2007). Soil Fertility Status As Influenced By Different Land Uses in Maybar Areas of South Wello Zone, North Ethiopia. MSc thesis, Department of Plant Sci., School of Graduate Studies, Haramaya Univ., 86p.

UNEP (1991). Global Assessment of Soil Degradation, UNEP. UN, GLASOG, Project.

USDA. (2004). Soil Survey Laboratory Methods Manual. Soil Survey Investigation Report No. 42 Version 4.0 November, USA.

Wahab, M.; Rasheed, M.; Youssef, R. A. (2010). Degradation Hazard Assessment of Some Soils North Nile Delta, Egypt, J. Am. Sci.; 6(6): 156-161.

Zhang, J.; Niu, J.; Bao T.; Buyantuyev, A.; Zhang, Q.; Dong, J. and Zhang, X. (2014). Human Induced Dryland Degradation in Ordos Plateau, China, revealed by Multilevel Statistical Modeling of Normalized Difference Vegetation Index and Rainfall Time-Series. J. Arid Land 6(2): 219-229.

\section{عنوان البحث: استخدام النمذجة الخرائطية لتقييم تدهور الأراضي في محافظة دمياط، مصر

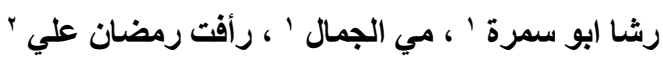

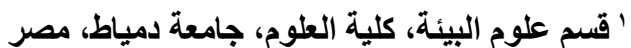

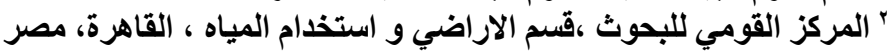

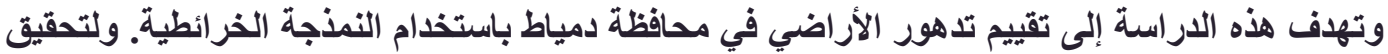

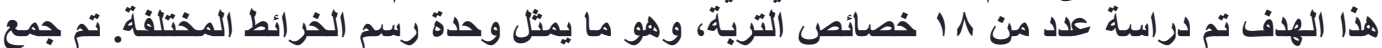

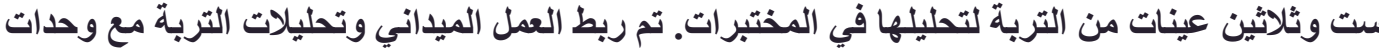

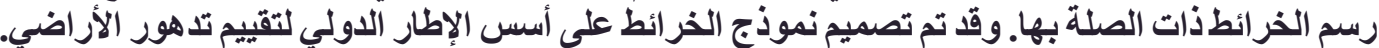
أشارت النتائج إلى أن منظقة كبيرة من محافظة مهرد من قبل فيل ارتفاع خطر التد هور.
} 